\title{
Analyses of Factors Affecting the Production of Broiler Chickens in Ternate
}

\author{
Nurdiyanawati Djumadil ${ }^{1, *}$, Yunus Syafie ${ }^{2}$ \\ ${ }^{I}$ Department of Agribusines, Faculty of Agriculture, University of Khairun, Ternate, Indonesia \\ ${ }^{2}$ Department of Animal Husbandary, Faculty of Agriculture, University of Khairun, Ternate, Indonesia \\ ${ }^{*}$ Corresponden Author, e-mail: diyana.waty@yahoo.co.id
}

\begin{abstract}
A rising interest in animal protein consumption produced from chickens in North Maluku has stimulated the development of broiler chicken farms across the region. However, broiler chicken farmers have been facing a big challenge in developing their small businesses due to costly production factors. The present study aimed at observing whether or not factors that influence the production of broiler chicken. An investigation was conducted at a Broiler Chickens Farming System developed by the RegionalTechnical Implementation Unit for Agribusiness and Livestock in Ternate from July to September 2018. The reason for selecting this area as the study site was that the chicken farm has utilized modern technology in developing this business and the farm has produced its own chicken feed. An Interview was conducted to collect data. The production factors observed consisted of the use of day-old chicken (DOC), area of the chicken house, chicken feed, antibiotic, labor, and operational cost. The data were then analyzed using a multiple linear regression model. The findings revealed that from all production factors, DOC, area of the chicken house, chicken feed and operational cost had significant effects on chicken production, while the other two factors (antibiotics and labor) had no significant effects on the production.
\end{abstract}

Keywords: broiler chicken, production factors

\section{INTRODUCTION}

Chicken farming is one of the potential businesses that support Indonesian commerce. The broiler type of farming in particular is the most prospective type, which is excellent for big, medium, and even small scale of businesses in providing animal-based protein to support the social and economic demand [1]..

The success of broiler chicken farming is influenced by such factors as non-crowded environmental conditions, adequate feed procurement, human resources with decent farming knowledge, skill, and yield management. In the broiler chicken farming business, one of the parameters that can be used to measure the success of a business is the level of profits obtained by utilizing the production factors efficiently. The combination of production factors in each business is an appropriate requirement to get profit, which can be examined by measuring the technical and economic efficiencies [1].

The RegionalTechnical Implementation Unit [UPTD] for Agribusiness and Livestock was established upon the regulation by the Mayor of Ternate, Number 17, 29 December 2006. It aims to organize and develop livestock farming businesses at local level, as an information center for agribusiness and animal husbandry development, and to support the fullfilment of public demand for animal meat.
Broiler chicken farm developed by UPTD for Agribusiness and Livestock at Sasa village in Ternate region is a small scale business owned by the local government, specifically the Department of Agriculture. This business is developed as an attempt to increase the fulfillment of broiler chicken meat demand across the region. The effort is intended to meet the need for chicken meat that is commonly higher than the supply. In addition, This is the way to reduce the dependency on the import of chicken meat from outside Maluku Utara Province due to limited production .

Up to 500 tons of chicken meat is brought to Ternate every month when coinciding with moments of religious holidays. Hence, the government of Ternate, through the Department of Agriculture as well as the Department of Food Security, encourage local businessmen to develop broiler chicken farming to fulfill public demand across this region.

The broiler chicken farming business of UPTD for Agribusiness and Livestock, Ternate, has been able to stay afloat since 2006, despite various challenges that they faced. It is noted that there are some factors playing an important role in the survival of this business. Hence, the present study on "Analyses of Production Factors for Broiler Chicken Farm Business in RegionalTechnical Implementation Unit [UPTD] for Agribusiness and Livestock located in Sasa Village, Ternate, was conducted. 


\section{MATERIALS AND METHODS}

\subsection{Study site}

The study was conducted at the RegionalTechnical Implementation Unit[UPTD] for Agribusiness and Livestock at Sasa Village, Ternate. The location was selected purposively based on the reason that the business has a high potential in developing broiler chicken breeding. The research was conducted in September 2018.

\subsection{Methods of data collection}

The data collection methods used in the study were:

- Observation, which involved collecting data through direct observation on the location of the broiler chicken farm, particularly throughout the production activities[input-process-output].

- Interview, which involved data collection through questions and answers session with the business managers of broiler chicken regarding production factors; area [cage], capital [including production and marketing costs], labor [required human resource], and management.

The data collected in the study were primary and secondary data. The primary data was obtained from a direct and structural interview with respondents using a pre-prepared list of questions (questionnaire). The sample unit for the interview included the management of the RegionalTechnical Implementation Unit[UPTD] for Agribusiness and Livestock [manager and staff]. Meanwhile, secondary data were collected from the Department of Agriculture as well as Statistics Office.

\subsection{Data analysis}

The data were then analysed using a multiple linear regression. The analyses were intended to draw the relationship between productions fators and technical and economic efficiency in the development of the broiler chicken farming business.

Hypothesis test through regression analysis [2]. Examining the production factors which are assumed to influence the technical and economic efficiency in the development of the broiler chicken farming business. The hypothesis formulation is:

$$
\mathrm{Y}=\alpha+\beta_{1} \mathrm{X}_{1}+\beta_{2} \mathrm{X}_{2}+\beta_{3} \mathrm{X}_{3}+\beta_{4} \mathrm{X}_{4}+\mathrm{e}
$$

To examine the goodness of fit of the regression model, the coefficient of determination (R2) is used. The coefficient of determination provides hints regarding the goodness of fit of this model in explaining how big the changes are, while the dependent variable can be explained by the changes on the independent variables. Whilst to analyze the effect of the independent variableson the dependent variable, $F$ hypothesis test is used, as follows:

1. $\mathrm{H}_{0}: \beta_{1}=0$, means there is no significant difference between the independent variablse $(\mathrm{X})$ and the dependent variable $(\mathrm{Y})$
2. $\mathrm{H}_{1}: \beta_{1} \# 0$, means there is a significant difference between the independent variablse $(\mathrm{X})$ and dependent variable $(\mathrm{Y})$

The principles of the test are as follows: If $\mathrm{F}$ count $\leq \mathrm{F}$ table ${ }_{(0,05)}$, then $\mathrm{H}_{0}$ is accepted or $\mathrm{H}_{1}$ is rejected, which means that the independent variables $(\mathrm{X})$ has no significant effect on the dependent variable (Y).

\section{RESULTS AND DISCUSSION}

\subsection{The relationship between production factors}

The production function model assigned was the Cobb Douglas production function model. This was implied to explain the relationship of production factors in the production function. It was implemented by employing the multiple linear regression analysis, which was applied to the broiler chicken farming business at the UPTD for Agribusiness and Livestock. The factors used in speculating the broiler chicken production function were DOC - day old chicken (X1), area of the cage (X2), feed (X3), drugs (X4), labor (X5) and Operational Cost (X6), whichwas presented on Table 1.

Table 1 presented six independent variables with ten samples for each variable, as observed from the usage of production factors at the broiler chicken farming business at the UPTD for Agribusiness and Livestock. The total of broiler chicken processed in 10 rounds of production was $24.979 \mathrm{~kg}$ and the average weight of each chicken was $2.498 \mathrm{~kg}$. The total DOC was 20.200 chickens, with average DOC input of 2020 chickens. There are 8 units of broiler chicken cage at the UPTD, divided into starter and finisher cages. The area of each cage is $6 \times 8 \mathrm{~m} 2$. The total amount of feed required within 10 rounds of production was $73.250 \mathrm{~kg}$, with an average of $7.325 \mathrm{~kg}$ for each round.The drugs used included EM4, ND Vaccine, and vitamines when necessary.Furthermore, there is 2 permanent staff working at the UPTD. The operational cost consists of DOC, feed, drugs, labor, electricity, and other costs, which in total was around Rp. 769. 000.000, and Rp 76.900 .000 for each period of production.

\subsection{Results of Multiple Linear Regression Analysis}

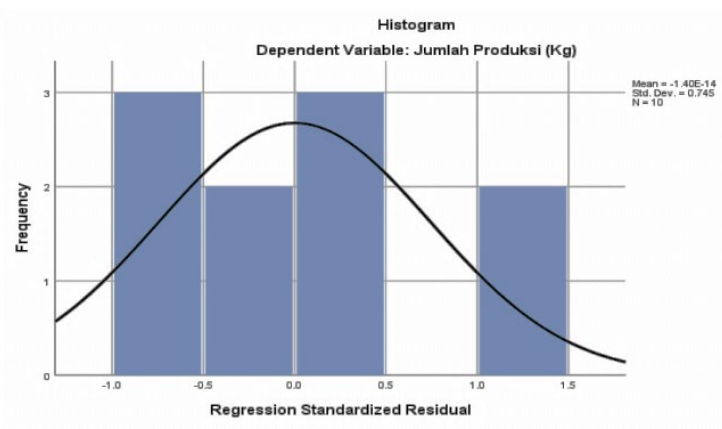

Fig 1. Total of chicken production 
Regression analysis in this study is used to test how big an effect of the usage of production factors such as DOC, cage area, feed, medicine, labor and operational cost on the total of production (chicken weight). It is shown in Figure 1 below.

Figure 2 presented the normal probability plots, which shows that the dots follow and approach the diagonal line from zero (0) and do not extend too far from it. The probability for a residual standard or standard deviation is 0.745, which means positive. Therefore it can be concluded that the regression model meets the normal assumptions or normally distributed data.

The results of multiple linear regression tests are used to examine the research hypotheses that have been outlined in the previous chapter, namely to determine the effects simultaneously. Independent variables, namely DOC (X1), Cage Area (X2), Feed (X3), Medicines (X4), Labor (X5) and Operational Costs (X6) affect the dependent variable, which includes the number of chickens production or weight

Table 1. Description of Broiler Chicken Farming Business at UPTD for Agribusiness and Livestock at Sasa Village in Ternate City

\begin{tabular}{|c|c|c|c|c|c|c|c|}
\hline No. & $\begin{array}{c}\text { (Y) } \\
\text { Total of } \\
\text { Production }\end{array}$ & $\begin{array}{c}\text { X1 } \\
\text { DOC (per } \\
\text { chicken) }\end{array}$ & $\begin{array}{c}\text { X2 } \\
\text { Area of } \\
\text { Cage (M2) }\end{array}$ & $\begin{array}{c}\text { X3 } \\
\text { Feed } \\
(\text { Kg) }\end{array}$ & $\begin{array}{c}\text { X4 } \\
\text { Drugs(gr) }\end{array}$ & $\begin{array}{c}\text { X5 } \\
\text { Labor } \\
\text { (HKP) }\end{array}$ & $\begin{array}{c}\text { X6 } \\
\text { Operationa } \\
\text { Cost }(\mathbf{R p})\end{array}$ \\
\hline 1 & 2145 & 1700 & 164 & 6000 & 666 & 2 & 58000000 \\
\hline 2 & 2535 & 2000 & 192 & 7500 & 784 & 2 & 80500000 \\
\hline 3 & 2535 & 2000 & 192 & 7500 & 784 & 2 & 80500000 \\
\hline 4 & 2535 & 2000 & 192 & 7500 & 784 & 2 & 80500000 \\
\hline 5 & 2850 & 2500 & 250 & 8500 & 920 & 2 & 88000000 \\
\hline 6 & 2548 & 2000 & 192 & 7500 & 784 & 2 & 80500000 \\
\hline 7 & 2548 & 2000 & 192 & 7500 & 784 & 2 & 80500000 \\
\hline 8 & 1898 & 1500 & 144 & 5250 & 588 & 2 & 52000000 \\
\hline 9 & 2850 & 2500 & 250 & 8500 & 920 & 2 & 88000000 \\
\hline 10 & 2535 & 2000 & 192 & 7500 & 784 & 2 & 80500000 \\
\hline Total & 24.979 & 20.200 & - & 73.250 & 7.798 & 2 & 769.000000 \\
\hline Average & 2.498 & 2.020 & - & 7.325 & 779,8 & 2 & 76.900000 \\
\hline
\end{tabular}

The histogram graph above presents an even distribution pattern, which means that the distribution data is normal because the ratio value is at intervals of -2 to 2 .

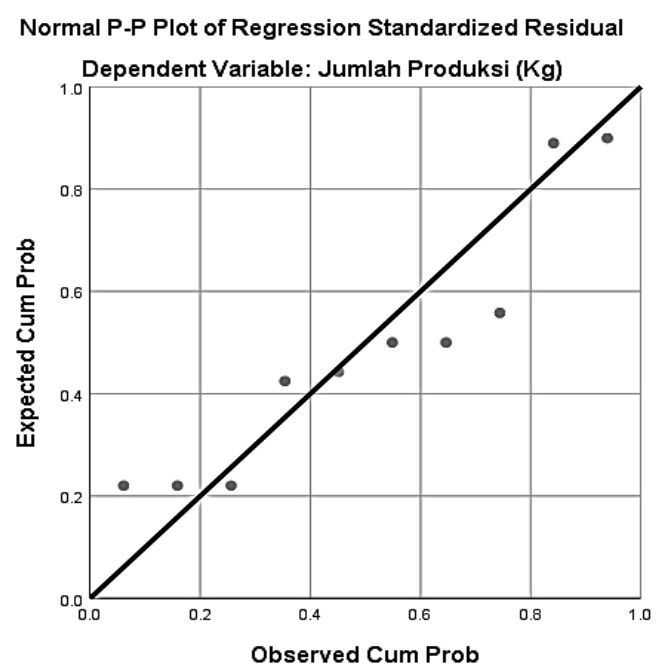

Fig 2. Normal Probability plots test

Descriptive results of the DOC variable (X1) in the Descriptive table explain that there were a number of samples $(\mathrm{N})=10$ data samples, an average (Mean) of 2020 chicken, cage area (X2) means of $196 \mathrm{~m} 2$, feed (X3) means of $7325 \mathrm{~kg}$, Medicines (X4) means of $651 \mathrm{gr}$, Labor (X5) of 2 people and Operational Cost (X6) mean of Rp. $76,900,000$. The mean of production (Y) total was 2497 $\mathrm{kg}$, while the standard deviation was 287,304 .

The result of the correlation between the DOC variable (X1) with Total Production (Y) of 0.962 had a significant level of 0.000 that was smaller than the probability value of 0.05 , which indicated a significant relationship. The result of the correlation between the cage area (X2) variable with total production (Y) 0.939 had a significant level of 0,000 which was smaller than the probability of 0.05 . Therefore, there was a significant relationship between the cage area variable and the total number of production.

The result of the correlation between the feed (X3) variable and the total production $(\mathrm{Y})$ of 0.999 , the significant level of 0,000 was smaller than the probability of 0.05 . That means that there was a significant relationship between the feed variable with the total of production. The result of the correlation between drugs (X4) and a total production (Y) of around -0.158 , the significant level of 0.332 that was greater than the probability of 0.05 . Hence, there was no significant relationship between the variables of drugs and total production. There was also no correlation between the labor (X5) and the total of production (Y) because the labor still does not affect the input used. The correlation results Operational Cost (X6) with total production (Y) of 0.975 with a significant level of 0,000 that was smaller 
than the probability of 0.05 , indicating that there was a significant correlation between the Operational Cost and the total production.

The results of the Summary model table displayed the value of $\mathrm{R}=1,000$, the coefficient of determination ( $R$ Square) of 1,000 and the adjusted R Square of 0.999 . That means that the total production (Y) was $99.9 \%$ affected by the variables (X1, X2, X3, and X6), with S Square values ranged from $0-1$.

From the table of coefficient, the $\mathrm{T}$ count values for $\mathrm{X} 1$, $\mathrm{X} 2, \mathrm{X} 3$, and $\mathrm{X} 6$ were greater than the values of the T table, then it had a significant effect. Conversely, the $T$ arithmetic for X4 and X5 were smaller than the T table, meaning that there had no significant effect.

\subsection{Discussion}

The efficiency of the use of Production Factors and their effects on the Total Production

The purpose of the study was to determine the value of efficiency in the use of production factors on the broiler chicken farming business in the UPTD For Agribusiness and Animal Husbandry at Sasa Village, Ternate. Production factors used as the independent variables in the study were DOC, Cage Area, Feed, Drugs, Labor, and Operational Cost. Simultaneously, the contribution of these six factors to total production was $99.9 \%$. This shows the magnitude of these factors as determinants of the total production.

The DOC factor had a significant effect on total production. This was based on the analysis results of the influence of DOC on total production, which was around 0.962 , and a significant level of 0.000 which was smaller than the probability of 0.05 . This indicated that the seeds (DOC) produced had a good genetic makeup that will produce fast growth, good survival, and high productivity. The cage area factor also had a significant effect on total production. The result of the analysis of the cage area, with a total production of 0.939 and a significant level of 0,000 that was smaller than the probability of 0.05 , indicated that the cage area in the UPTD influenced the cage density. There were 8 units of cages in UPTD with the dimension of $6 \times 8 \mathrm{~m} 2$ per unit, which fulfilled the ideal assumptions in measuring the density of the cages. This ideal measurement of the cage could prevent stress. If the cage density is not ideal or exceeds this number, especially during the daytime in adulthood (finisher phase) where cage temperature rapidly increases, it may cause chickens to become stressed, growing stunted and easily attacked by young disease.

Another significant influence on total production was shown by the feed factor. From the results of the analysis of the effect of feed on the total production of 0.999 , the significant level of 0.000 was smaller than the probability of 0.05 . This indicated that feed had a very significant effect (almost $100 \%$ ) on total production (chicken weight) because the feed had an important role in relation to economic aspects. It covers $65-70 \%$ of total production costs incurred. Feeding aims to meet basic living needs, growth, maintenance of body heat and production.

The drug factor had no significant effect on total production. From the analysis of the influence of drugs on the total production of -0.158 , a significant level of 0.332 was greater than the probability of 0.05 , meaning that there was no significant relationship between the factors. This indicated that drugs do not always affect the optimal total production. If factors such as DOC, feed, and cage density have fulfilled the ideal or normal assumptions, the use of drugs will decrease. The less use of drugs is better, as drugs can also cause negative effects, including residues in the carcass of chicken meat which makes the meat dangerous for consumers.

For the labor factor, the labor variable in the study was the two permanent staff at the UPTD. From the result of the analysis, the number of labors did not meet the assumptions for a statistical test because it did not affect the input used. This means that whatever input is used, the number of labors remains the same.

The operational cost factor hasd a significant effect on total production. From the analysis of the effect of operating costs on total production, which was around 0.975 , the significant level of 0,000 was smaller than the probability of 0.05 . This indicated that $97 \%$ of operational cost factors had a significant effect on total production. Hence, technically, the use of production factors in the maintenance period was efficient. Furthermore, it was also economically very efficient because the total production expenditure had met the needs of the use of production factors.

\section{CONCLUSION}

In the test of total production, there were six variables that $99,9 \%$ influenced the total production simultaneously. Partially, there were only four variables with significant effects namely the DOC variable, the cage area variable, the feed variable, and the operational cost variable. Whereas two other variables, drug and labor variables, affected insignificantly on the total production. Thus, technically, the use of production factors in the maintenance period was efficient. Economically, this was very efficient as well because the total cost of production that was expended had fulfilled the needs of the use of production factors.

\section{ACKNOWLEDGMENT}

The authors would like to express their sincere gratitude to the Board of Research and Community Service of Khairun University and Faculty of Agriculture, Khairun University for financial support. They also highly appreciate the assistance provided by the Agribusiness Regional Technical Implementation Unit and the Broiler nursery of the Ternate City Agriculture Office for all facilities provided during the study. 


\section{REFERENCES}

[1] Afifah F 2012. AnalisisPengaruhFaktor Modal, Biaya, TenagaKerja Dan Bahan Baku Terhadap Tingkat KeuntunganPengusahaIndustri Batik di DesaJarumKabupatenKlateng.UniversitasSebelasM aret Surakarta.

[2] Gujarati. (2005). SPSS Versi 16 Mengolah Data Statistik Secara Profesional. Jakarta: Gramedia Pustaka Utama.

[3] Agus T.B dan E.P 2015.Regresi dalamvPenelitian Ekonomi dan Bisnis. Yogyakarta: Danisa Media

[4] Aziz N 2013. Pengantar Ekonomi. Malang; Banyumedia

[5] E.A.M Bokkers\& I.J.M. de Boer. 2009. Economic, Ecological, and Social Performance Conventionl and Organic Broiler Production in the Netherlands. Journal British Poultry Science Vol. 50 , issu 5.

[6] Rasyaf 2005. Beternak Ayam Petelur, Penebar Swadaya. Jakarta
[7] Rasyaf, Muhammad. 2008. Panduan Beternak Ayam Pedaging. Jakarta. Penerbit Penebar Swadaya

[8] Ricardo Brando Mansilha, Dalila Cisco Collatto, Daniel Pacheco Lacerda, Maria Isabel, Wolf Motta Morandi, Fabio Sartori Piran., .2018. Environmental Externalities in Broiler Production: An Analysis Based on System Dynamics. Journal of Cleaner Productition 209. DOI: 0.1016/j.jclepro2018.10.179

[9] Sunarno Sunarno, Sutrisno Hadi Purnomo, Endang Siti Rahayu. 2017. Factors Affecting broiler production in Wonogiri Regency. American Scientific Research Journal for Engineering, Tecnology, and Sciences (ASRJETS)

[10]S.O. OJO. 2003. Productivity and Technical Efficiency of Poultry Egg Production in Negeria. Internastional Journal of Poultry Science 2 (6): 459-464.

[11] Soekartawi 2006. Agribisnis Teori dan Aplikasi. Rajawali Press. Jakarta

[12] Sukirno, Sadono 2011.Makro Ekonomi Teori Pengantar, Jakarta; Rajawali Pers Jakarta 